\title{
流体摩擦場における撚分布について
}

$\begin{array}{lllll}\text { 東京工業大学工学部 } & \text { 清 } & \text { 水 } & \text { 郎 } \\ \text { 東京農工大学工学部 } & \text { 壁 } & \text { 矢 } & \text { 良 } \\ \text { 東京工業大学工学部 } & \text { 鳥 海 浩一郎 }\end{array}$

\section{TWIST DISTRIBUTIONS IN THE FIELD OF LIQUID FRICTION*}

\author{
By Jiro Shimizu,** Hisayoshi Kabeya*** and Koichiro Toriumi** \\ **(Tokyo Institute of Technology, Ookayama, Meguroku, Tokyo, Japan) \\ ***(Tokyo University of Agriculture and Technology, Faculty of Technology, \\ 2-24-16 Naka-machi, Koganei-city, Tokyo, Japan)
}

The twist distributions along a yarn depends on the properties of the yam and on the mechanism of yarn-twisting (false twister, open end spinning and ring spinning frame).

In this study, the twist distributions of yam prepared under the various friction conditions are experimentally investigated, and numerically discussed for the yarn twisted in the high viscous fluid.

1) It was recognized that the twist of the rotating yarn in the fluid distributes along the yarn axis, which is due to the fluid friction.

2) When the twist distribution of the rotating yarn in the fluid is measured under constant tension, the moment of fluid friction $M_{Y}$ is described by the following equation, in which the flow of the fluid is treated as Couette flow.

$$
M_{Y}=4 \pi h_{Y} \eta g /\left(1 / R_{Y}{ }^{2}-1 / R_{P}{ }^{2}\right)
$$

$h_{Y}$ : yarn length in the fluid $(\mathrm{cm})$

$\eta:$ viscosity (dyne $\cdot \mathrm{sec} / \mathrm{cm}^{2}$ )

$\theta$ : angular velocity $(\mathrm{rad} / \mathrm{sec})$

$R_{Y}:$ radius of the yarn $(\mathrm{cm})$

$R_{P}:$ radius of the pipe $(\mathrm{cm})$

3) The rigidity of the yarn under constant tension is measured by using the apparatus showing in fig. 3 .

4) The rigidity of the yarn depends on twist and tension.

(Received August 3, 1973)

\section{1. 緒訔}

仮撚機、リング精紡機,オープンエンド精紡機など系 の加工機においては、それぞれ独特の加撚機構を有して いる。このような加撚機構における共通の問題点の一つ として, 加然子からの系への撚の层達機構の問題がある。 促来，この種の機構では加撚子が比較的低速に回転し， 系が空気中に走行または停止の状態で加然されるものが 主であったが，仮撚機やオープンエンド精紡のロータ中 の加撚機構では采は常に周囲の界面との接触により撚の 伝達を妨げられつつ加撚される。すなわち、このような 加撚機構では糸の撚は常に加撚トルクと界面との接触に よる摩擦力とのバランスで分布し，串た伝播していると いってよい。

本研究は。このような撚伝達状態につき摩擦埸の影響

*この報文を「系の加撚機構に関する研究（第 1 報）・

Studies on Yarn Twisting (Part 1) J とする
について基礎的な解析を行なおうとするものである。 米の加撚状態に関寸る研究は，田中道一”，K. Baird ${ }^{2)}$ ， 黑崎新也他 ${ }^{8)}$. J. J. Thwaites ${ }^{4)}$ らの研究があり，1）， 2）は空気中での撚の伝達速度に関するものであり，3）, 4) 沬主として加然子の機構に関するもので, 撚の层達 におよぼす摩擦の影慧に関するような基磷的研究は少な い。一方，系の撚構造については多くの研究"が報告さ れているが, 系のトルクやミグレイションについてのも ので、撚の层達との関連においては報告されていない。 本報では，高摩摖場の一つとして摩擦因子が比較的単 純な流体を対象として高粘性流体中で系を加撚したとき の然の伝達，とくに定常状熊に扔いての然分布について 檢討した。

\section{2. 実験万法およひ理諭的検討}

\section{1 実験貝置および方法}

Fig.1 岋装置の概要である。透明フクリル円筒に粘性 
流体を入れ、これに同心軸となるよ5に円柱状重鍾を吊 した糸を下げ，シンクロナスモータによって上端を一定 速度で回転する。この場合, 米には流体の粘性抵抗に釣 合うモーメントが加えられ，一定の撚がかけられる。粘 性抵抗は重鉏と采自身に加わるもののため, 上部ほど多 くの撚がかかる。撚分布は, 糸の回転が定常状態に達し た時点で上方より一定間隔 $(15 \mathrm{~cm})$ で写真撮影をして 求めた。Fig. 2 は装置の外観を示したものである。

糸の剛性率, 表面構造の影響を考慮し, 試料はモノフ ィラメント・マルチフィラメント・紡績系の三種を用い, 摩擦場としての流体は透明度のよいグリセリンを用いた。 張力および回転速度は, 試料系に発生する snarl を防 止するため適当な重䥀が必要でありそれぞれ Table.1 のように定めた。

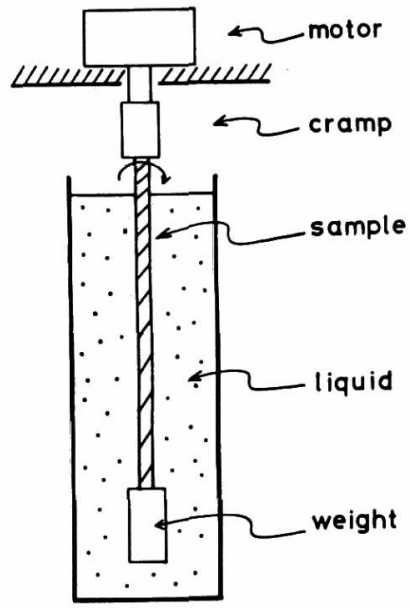

Fig.1 Twisting apparatus by high viscous liquid. The sample yarn with a cylindrical weight $\left(R_{W}\right)$ is set up in the center of a transparent cylindrical pipe $\left(R_{P}\right)$, which is filled up with viscous liquid. Continuous distributions of twist are given by balancing with twisting torque and viscous resistance of liquid.

Table 1 Experimental conditions

\begin{tabular}{|l|l|}
\hline Sample & $\begin{array}{l}\text { (a) nylon mono-f.(0.161 dia.) } \\
\text { (b) nylon multi-f.(210d } / 24 \times 6) \\
\text { (c) cotton spun yarn(0.E 20'S) }\end{array}$ \\
\hline Revolution & $25,50,100,200$ r.p.m. \\
\hline Liquid & glycerin 10 poise \\
\hline Tension & $1 \mathrm{~g}, 2 \mathrm{~g}, 3 \mathrm{~g}, 5 \mathrm{~g}$ \\
\hline Condition & $22 \pm 2^{\circ} \mathrm{C}$ \\
\hline
\end{tabular}

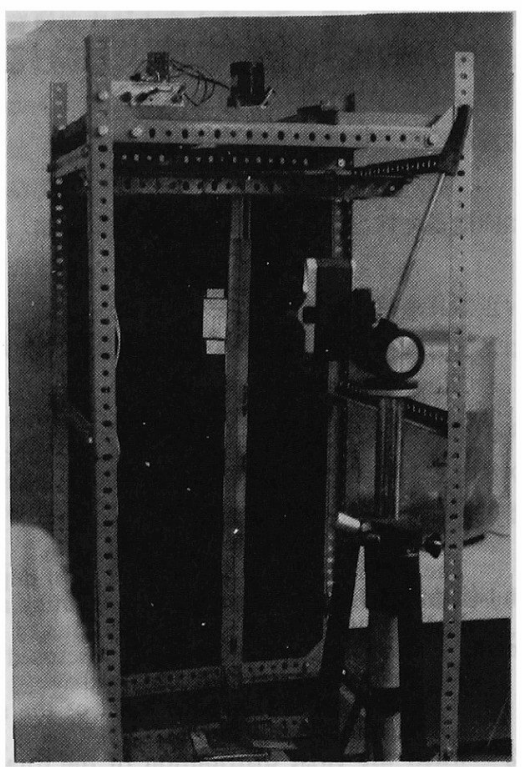

Fig.2 Experimental appartus.

流体中への糸の浸漬長は 70〜 $75 \mathrm{~cm}$ として前述のよ 5に定常状態で写真撮影を行ない, 米軸方向に $2 \mathrm{~cm}$ 毎 に $4 \mathrm{~cm}$ 間の平均撚数を計測算出し, 単位長当りに換算 した。

撚数の観測のため，モノフィラメントでは瀻維片面に 黒色インクを塗布し，マルチフィラメントでは合系の一 部を染色し，紡績系では $20 \mathrm{~d} / 7$ の染色マルチフィラメ ントを合せて加撚した。一般に加撚時に扔ける㓮性率は 撚数・張力に依存することが見出されたので，剛性率の 測定はFig. 3 に示すよ5に張力の変化は空気中に別途の 重錘を吊して行なった。（大きな張力を与えるために流 体中に大きな重錘を用いると、流体から受ける摩擦抵抗 が増大し，過多の撚が系にかけられ，snarlが発生す る。)

\section{2 実験に対する理論的検討}

流体中で采を回転・加撚したときの撚数の分布状態は 各試料系を円形断面の弾性体と仮定し，流体の運動を同 心二重円筒内のクェット流と仮定すれば，定常状態にお ける両者のモーメントのつり合いから以下のように解析 される。

まづ，Fig.4に示すように中間の径 $r$ における流体の ずり速度 $\dot{\varepsilon}$ は，角速度を $\omega$ として

$$
\dot{\varepsilon}=r \frac{d \omega}{d r}
$$




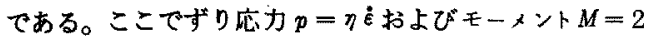
$\pi r^{2} h p$ を用いると（1）式は，

$$
d \omega=\frac{M}{2 \pi \eta h} \frac{d r}{r^{9}}
$$

となる。たたしう：粘性係数， $h$ : 円筒脣

米件 $\omega=\Omega_{0}\left(r=R_{0}\right), \omega=\Omega_{i}\left(r=R_{i}\right)$ 加 $5(2)$ 式 を解いて回転粘生流体の $M($ dyne $\cdot \mathrm{cm})$ を求めると，

$$
M=4 \pi h \eta \frac{\Omega_{0}-\Omega_{i}}{\left(1 / R_{i}^{2}-1 / R_{0}^{2}\right)}
$$

したがって、前述の実駼装置では流体の粘性抵抗によ って生ずる円柱重鉷のモーメント $M_{W}$ 、采のモーメント

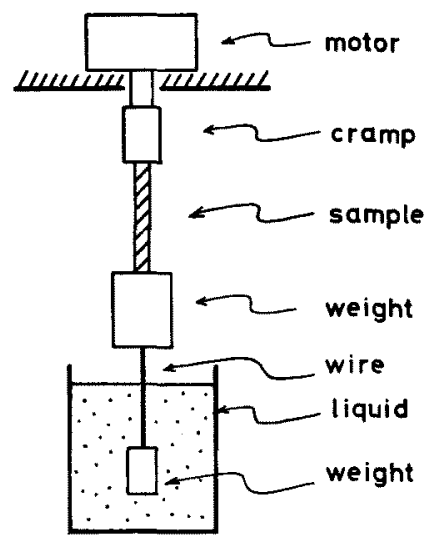

Fig.3 Each yam rigidity is measured by the same apparatus of fig. 1 . In such a case, a large cylindrical weight is required to be set at a tail-end of the yarn in order to prevent to make snarl.

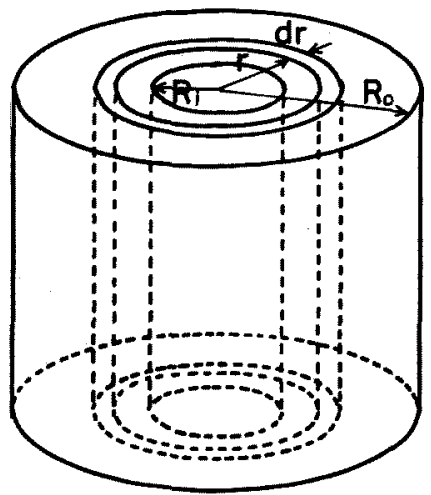

Fig.4 Cylindrical shell model for the calculation of viscous resistance on the surface of a yarn. $R_{i}$ is a radius of inner cylinder and $R_{0}$ a radius of outer cylinder.
$M_{Y}$ は (4)，(5) 式となる。

$$
\begin{aligned}
& M_{W}=4 \pi h_{W} \eta \Omega /\left(1 / R_{W}{ }^{2}-1 / R_{P}{ }^{2}\right) \\
& M_{Y}=4 \pi h_{Y} \eta \Omega /\left(1 / R_{Y}{ }^{2}-1 / R_{P}{ }^{2}\right) \\
& \text { ここで, } \Omega: \text { 角速度 }(\mathrm{rad} / \mathrm{sec})
\end{aligned}
$$

$h_{W}:$ 冈柱重鏵長 $(\mathrm{cm})$

$h_{Y}$ : 系と円柱重锤との接点からのモーメント

算出点までの糸長 $(\mathrm{cm})$

$R_{P}:$ 円筒内半径 $(\mathrm{cm})$

$R_{W}:$ 円柱重錘半径 $(\mathrm{cm})$

$R_{Y}:$ 系半径 $(\mathrm{cm})$

一方, 系のモーメントと撚数との関係は, 弾性体とし ての换り変形と考えると，(6)式で表わせる。

$$
M(x)=\pi^{2} d^{4} G n(x) / 16
$$

ここで $M(x)$ : 重銓と米との連結点からの距㕍 $x$ 点に おいて手に加わるモーメント (dyne $\cdot \mathrm{cm})$ $n(x): x$ 点での然数 $(\mathrm{T} / \mathrm{cm})$

$$
\begin{aligned}
& d: \text { 米の直径 }(\mathrm{cm}) \\
& G: \text { 米の㓮性率 }\left(\mathrm{dyne} \cdot \mathrm{cm}^{2}\right)
\end{aligned}
$$

(6) 式での $M(x)$ は (4)，(5) 式のモーメントの和であ って $M(x)=M_{W}+M_{Y}$ となり，(5) 式中の系長 $h_{Y}=x$ となる。（6）式加ら明らかなよらに撚数 $n(x)$ は，糸径 $d$, 用性率 $G$, および $M_{W}, M_{Y}$ 中に含まれる角速度 $\Omega$

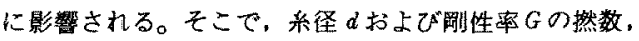
張力依存性について測定した。

\section{3. 害験結果と考察}

\section{1 測 定 例}

系に重錘を吊して流体中に浸清し、上端を回転させ糸 の回転が定常状態になったときの写真熶影結果例を Fig. 5 (a) (i)k示す。Fig.5 (a) 〜 (e) は試料がマルチフィラメ ント，回転数が 25 r. p.m.. 張力 $2.5 \mathrm{~g}$ の場合の浸清位固 の違いによる撚数分布状態の写真であり，Fig.5(f)〜(i) は試料がマルチフィラメント, 張力 $3.0 \mathrm{~g}$ の回転数の違 いによる撚数の状態を示したものである。浸漬長の大き くなるにつれて撚数は增加し，回転数の增加によって抵 抗モーメント增加のために然数が増加していることがわ かる。

\section{2 糸徍亡䦌性率の測定}

撚数と亲径との関係についての測定結果を Fig.6(a), (b)に示す。系径の測定はFig.7に示す装置により一定張 力下で加然し，A，B 2 点を slide glassに接着し, 万 能投埧機で計測した。系径はマルチフィラメント・紡績 手いずれも撚数の増加とともにわずかではあるが減少し てから增加する㑯向がある。また張力の增加によって減 少している。これは糸の内部圧力と撚角度による系樥造 の変化から理解できる。しかしその变化は微少であるの 


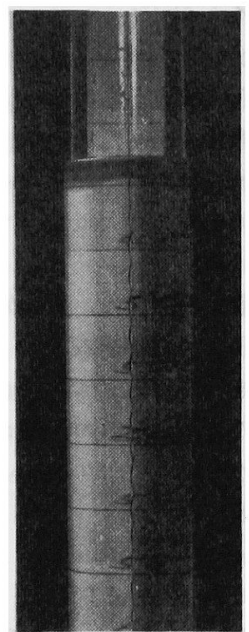

(a) Length $(\mathrm{cm})$

$0-12$

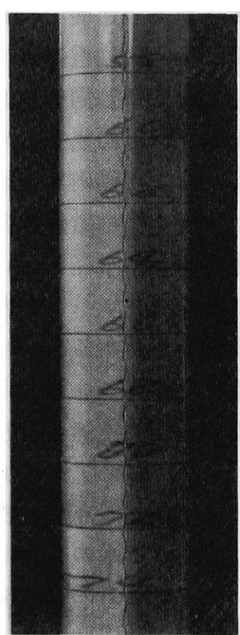

(b)

$12-28$

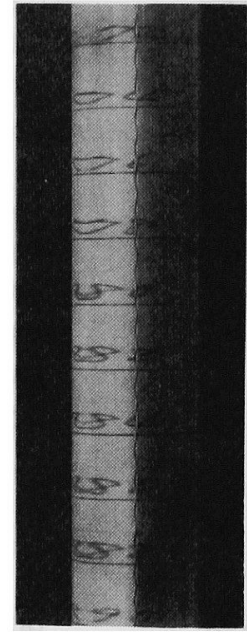

(c)

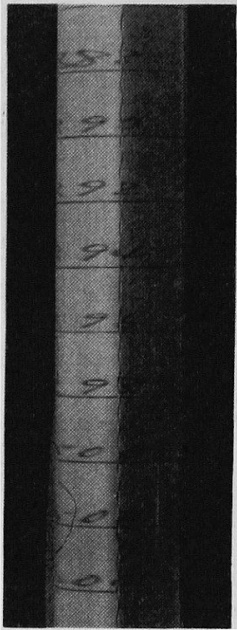

(d)

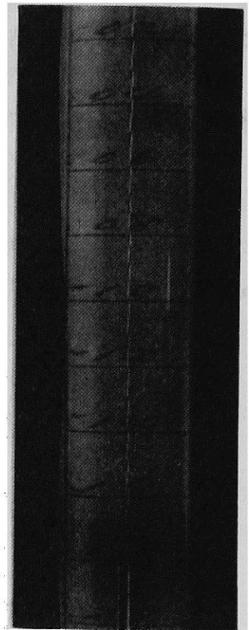

(e)

$26-42$

$42-58$

$56-72$

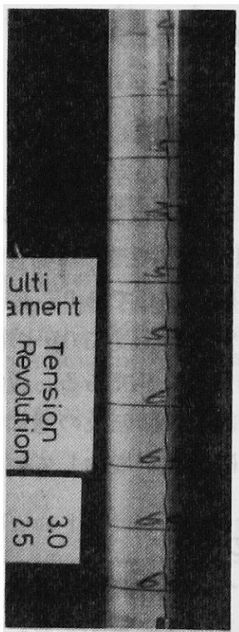

(

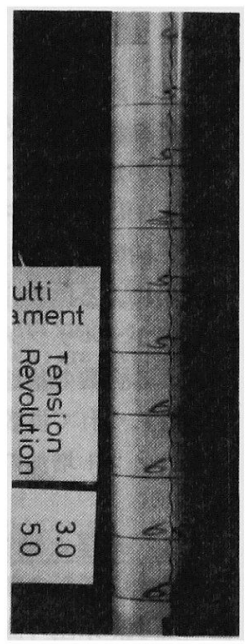

(g)

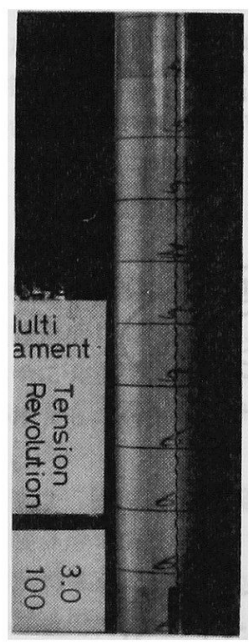

(h)

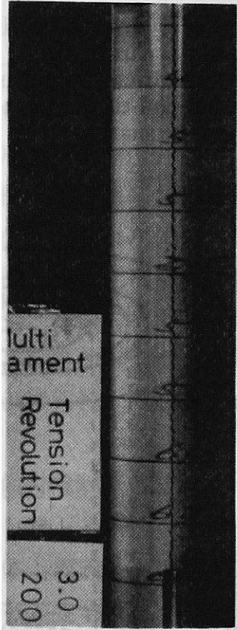

(i)

Fig.5 Twist changes

Fig. (a) $\sim($ b) : changes with the immersed length.

Sample : multifilament. Tension : 2.5g. Revolution : 25r.p.m.

Fig. (f) (i) : changes at differnt revolutions.

Sample : multifilament. Tension : $3.0 \mathrm{~g}$. 
で釆经は各条件下の算俦平均として求め、スパンーン は $2.42 \times 10^{-2} \mathrm{~cm}$ ：マルチフィラィント $5.02 \times 10^{-8} \mathrm{~cm}$.

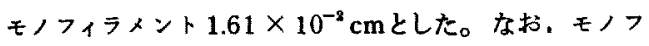

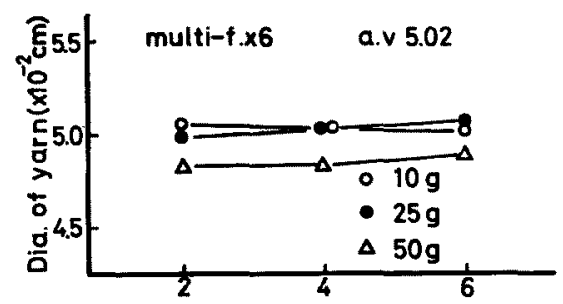

(a)

Twist $(\mathrm{T} / \mathrm{cm})$

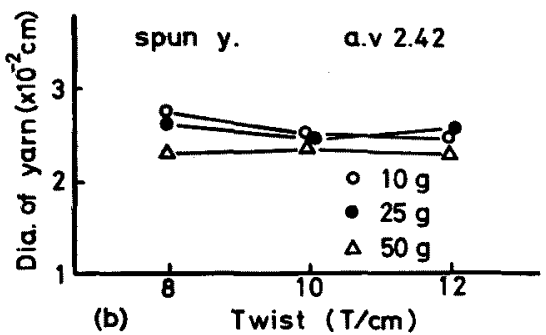

Fig.6 Relations between diameters of yarn and twists under various tensions. Fig. 6 (a): multifilament yarn. Fig. 6 (b) : spun yarn. Diameters of yam decreases slightly with the increase of tension and decreases at first and then increase slightly with the increase of twist.
ィラメントについては经の変化についての測定は行なっ

ていない。

㣚性率の測定結果をFig.8 (a)，(b)，(c)に示す。㓮性率 に関保する系のトルクについては, Milton M. Platt ${ }^{\circ}$ らや K. Baird ${ }^{2}$ ，W. E. Morton ${ }^{7}$ らの数多〈の報告が あり、いずれもトルクは糸を構成する絨稚数，ヤング率、 張力，撚数などによって影響されることを示している。 㓮性率を求める方法は，撚の伝達速度 ${ }^{2}$ ，流体回転 ${ }^{8)}$ に 上る方法などがある。

本実験ではFig.3に示した装膡によって，系に付与さ れる張力を任意に選び，張力一定の条件下で回転数を变 化させて，系に加わるもーメントとそのときの撚数とか ら (4)，(6) 式によって $M_{W}=M(x)$ として㓮性率を求め た。

Fig.8(a)はスパンヤーン,(b)はマルチフィラメント 6

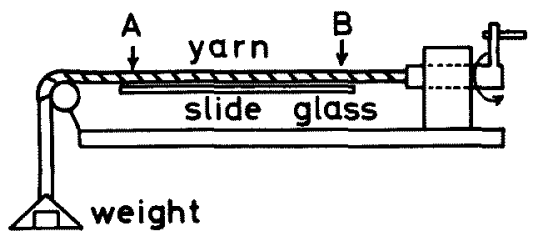

Fig. 7 The measurement of yarn diameters. A yarn is twisted under a given tension and is attached to the slide glass on the places between A and B. Twist is then measured by the profile projector.
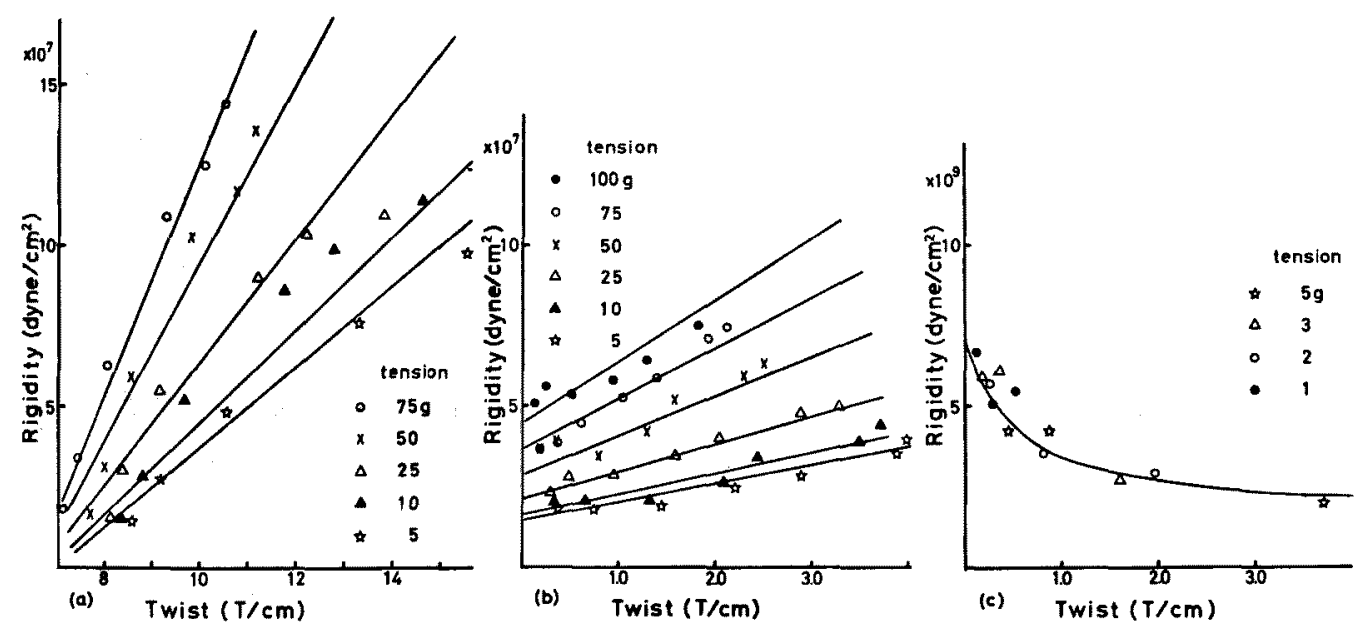

Fig. 8 Relations between rigidities and twists. Fig. 8 (a) : spun yarn. Fig. 8 (b) : multifilament $x 6$. Fig. 8 (c) : monofilament.

In fig. (a) and (b) rigidity increases with the increase of twist and tension, and in fig. (c)rigidity decreases. These experimental equations are obtained by the least square method. 
本合系（c)はモノフィラメントの結果である。プロット は実験值であり，最小自乗法により求めた奏験式からの 計算値を実線で示した。

スパンヤーンおよびマルチフィラメント系では然数なら びに張力の增加に対して岡性率は增加している。モノフ イラォント糸の場合は撚数の增加で則性率は減少して双 曲線型を示している。モノフィラィントでは，張力変化 の範囲が小さいため張力要因による差は認められない。 䦌性率が然の増加とともに減少していくのは㵶維自身の 変形量が増大し流動変形の領域になることから理解でき る。スパンヤーン、マルチフィラメントでは，然拉よび 張力の增加で采の内部王が增加して，岡珄率は增加する と考えられる。な括、スパンヤーンの撚数は元撚数を $7.94 \mathrm{~T} / \mathrm{cm}$ として算出している。（スパンャーンは, 熱湯で 1 時間以上撚七ットを行なっているが，その構造 上の性質で張力が付加されると解撚される。)

最小自乗法により求めた各試料系の威性率 $G$ (dyne／ $\left.\mathbf{c m}^{2}\right)$ ，然数 $n(\mathrm{~T} / \mathrm{cm})$, 張力 $T(\mathrm{~g})$ 関保の実験式 は $(7-\mathrm{a}),(7-\mathrm{b}),(7-\mathrm{c})$ 式で表わせた。

$$
\begin{aligned}
G_{S P}= & (0.0337 \cdot T \cdot n-0.212 T \\
& +1.06 n-7.36) \times 10^{7}
\end{aligned}
$$
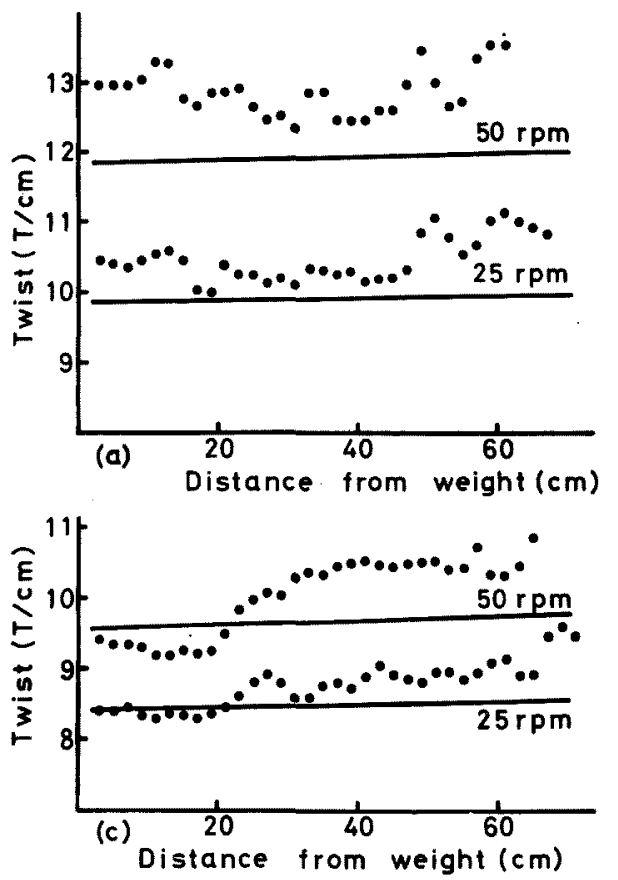

Fig. 9 Relations between twists and yarn length. The sample used is spun yarn. Fig. (a), (b), (c) and (d) show the cases when the tension is $5 \mathrm{~g}, 3 \mathrm{~g}, 2 \mathrm{~g}$ and $1 \mathrm{~g}$ respectively. Lines indicate the calculated values.

$$
\begin{aligned}
G_{M_{0}}= & (0.0142 T \cdot n+0.0316 T \\
& +0.512 n+1.30) \times 10^{7} \\
G_{M 0}= & (\{2.7 /(n+0.5)\}+1.6) \\
& \times 10^{9}
\end{aligned}
$$

剛性率 $G$ の添字 $S P$ はスパンャーン，M6はマルチフ イラメント 6 本合系，M0はもノフィラメントを意味す る。

\section{3 撚分布}

流体摩擦場に括ける回転中の系の撚数分布の実験結果 をFig.9〜11に示す。Fig.9はスパンヤーン,Fig.10 はマルチフィラメント系, Fig.11 はモノフィラメント 系である。横軸は糸と重錘との逴結点からのグリセリン 流体中の漫漬糸長であり，綎軸は $1 \mathrm{~cm}$ 当りの撚数であ る。プロット点は聿験值で，実線は (4)，(5)，(6)，(7) 式から求めた理猃值である。(a)，(b)，(c)，(d) 法張力，1 $\mathrm{g}, 2 \mathrm{~g}, 3 \mathrm{~g}, 4 \mathrm{~g}$ の場合で重鏵の形状は Table.2に 示した。張力の大きいものは重鏵の抵抗モーハントが大 のため系の然数は大きくなっており，回転数の増加によ っても撚数は増加している。また浸漬長の大きくなるに したがって撚数は多くなっている。これは系自身が流体 摩擦によって受ける抵抗モーメントのためであり、いわ
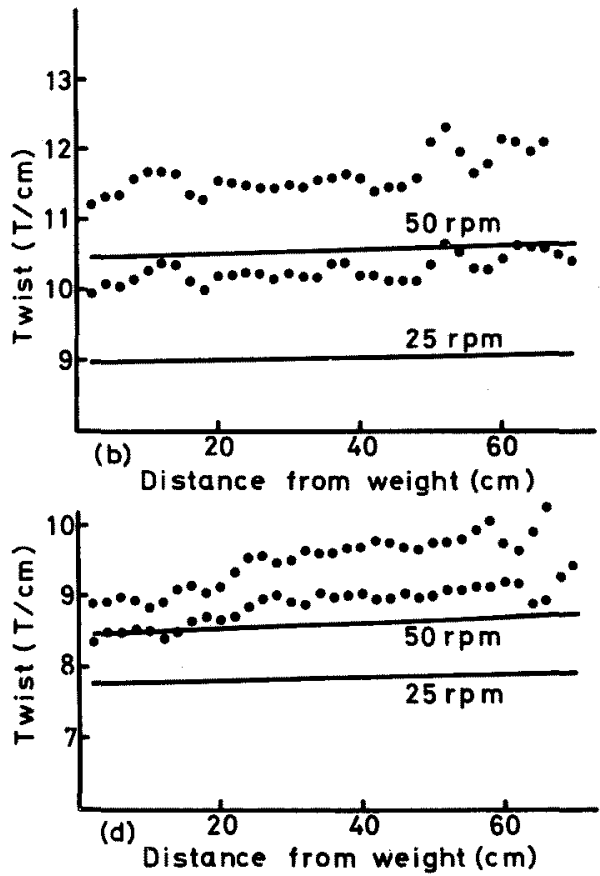
ば㬎の厷達椇失である。

Fig.9〜11からわかるように，実験値と理論計算值 とは一致した攧向が認められる。このことから流体中に 拈ける定常状態の然の伝達では，系は流体の粘性による 摩擦抵抗を受け，この場合にはクエット流として报った （5）式にあてはまることが確恋された。（5）式によれば， 摩擦抵抗モーメントは流体の粘性倸数，回転速度に比例 し、糸径に対して管径を充分大きく考えれば系径の二乗

Table 2 Dimensions of cylindrical weight

\begin{tabular}{|c|l|l|}
\hline Tension & Diameter & Length \\
\hline $1 \mathrm{~g}$ & $3.0 \mathrm{~mm}$ & $20.2 \mathrm{~mm}$ \\
\hline 2 & 3.45 & 30.4 \\
\hline 3 & 4.0 & 34.4 \\
\hline 5 & 5.5 & 30.15 \\
\hline
\end{tabular}
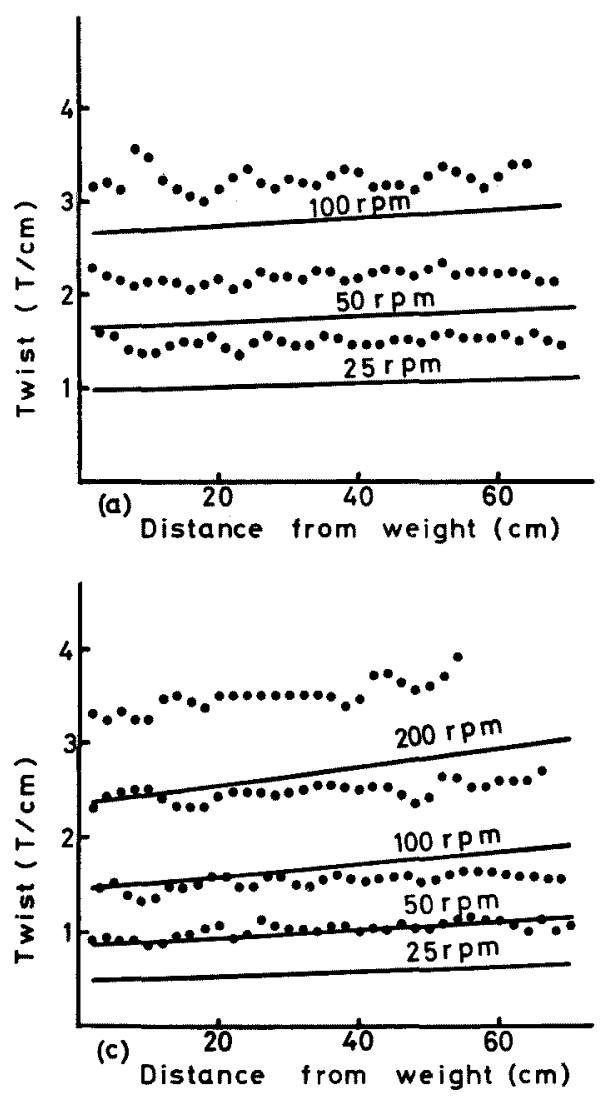

に比例する。系の撚数とモーメントの関保は（6）式で表 わされるから，系の撚数は系经 $d$ ，系㣚性率Gに依存す る。杀径は一般に然数と張力によって变化するが、ここ では一定值としていること，および用性率の算出も系径 に依存していることなどから，計算值と実鈋佔との絶対 値の差が生じていると考えられる。しかし，浸漬長によ って撚数の增加している傾问は一致していると考えられる。

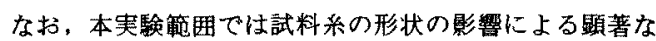
差は認められなかった。なお，系径は 2,3 例について測定 した結果，グリセリン中では筀気中に比べて約 $1 \%$ 強の差 が見られたが、計算值では空気中と同等として扱った。 又凨性率についても，撚数観測からは顕著な美は認めら れなかったので同様に空気中の值として算出してある。
4. 結
論

摩摖場が撚后達状態に与える埧㮒について奏験を行な
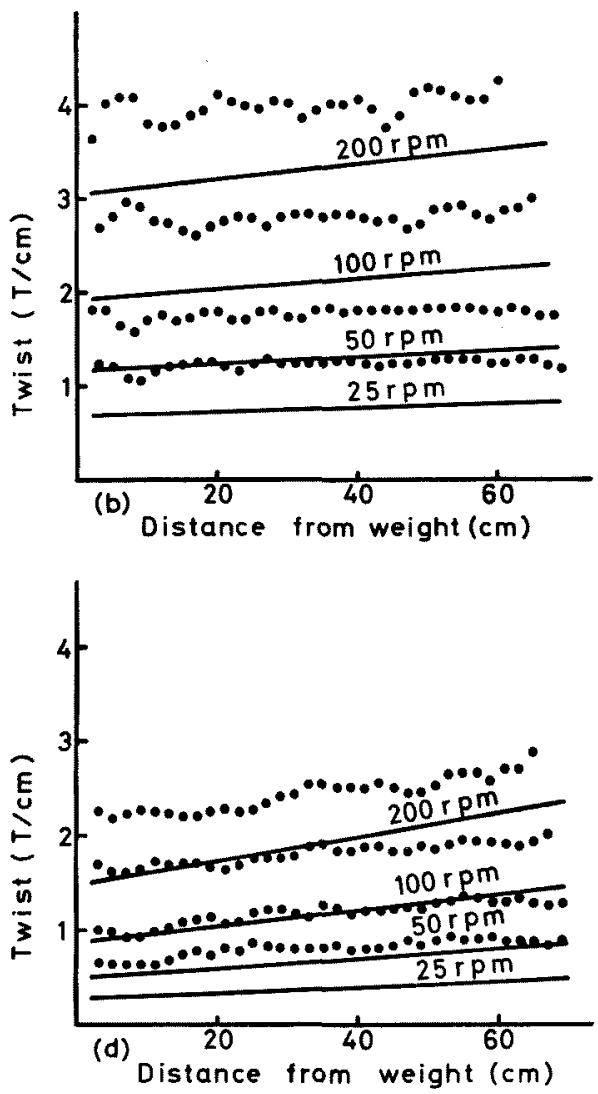

Fig.10 Relations between twists and yarn length. The sample used is multifilament. Fig. (a), (b), (c) and (d) show the cases when the tension is $5 \mathrm{~g}, 3 \mathrm{~g}, 2 \mathrm{~g}$ and $1 \mathrm{~g}$ respectively. Lines indicate the calculated values. 

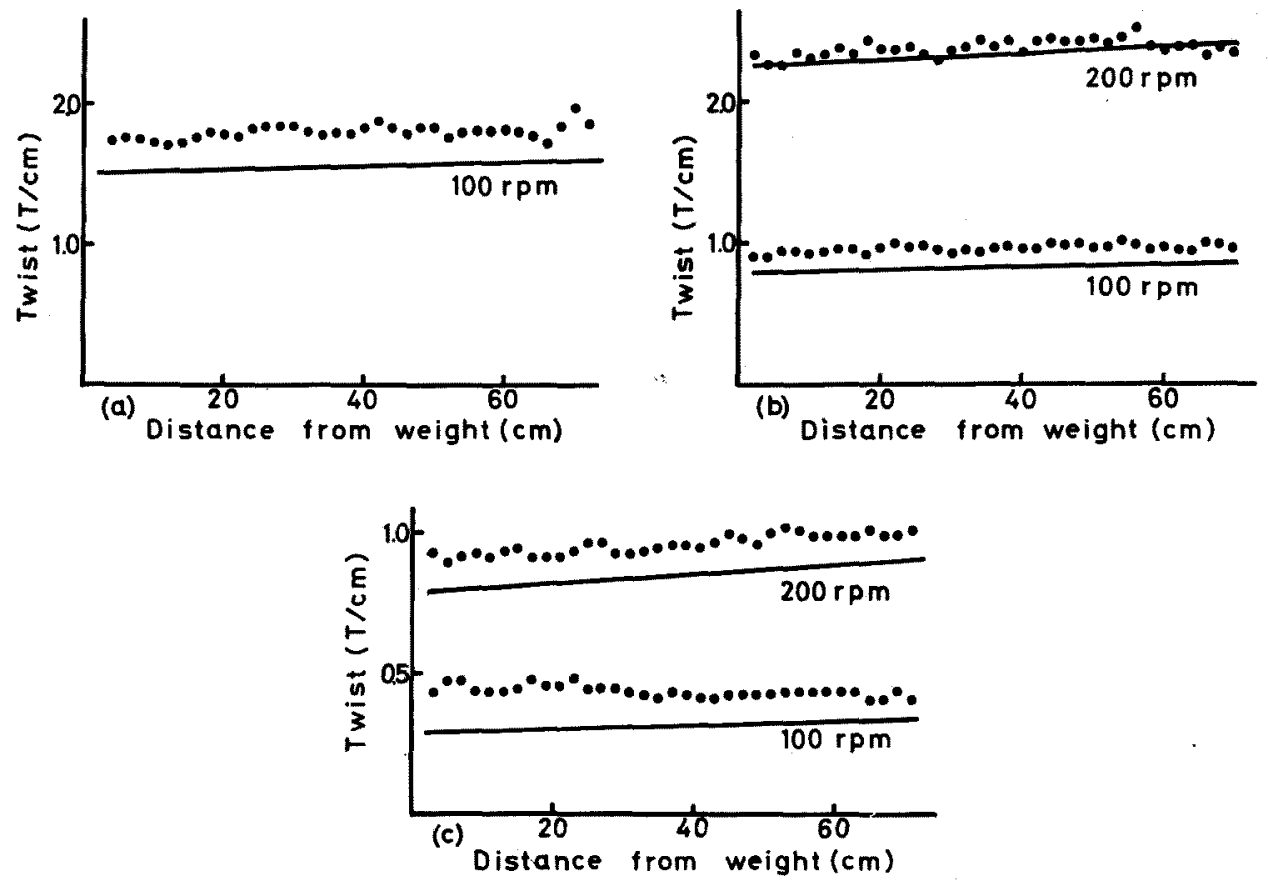

Fig. 11 Relations between twists and yarn length. The sample used is monofilament. Fig. (a), (b) and (c) show the cases when the tension is $3 \mathrm{~g}$, $2 \mathrm{~g}$ and $\mathrm{lg}$ respectively. Lines indicate the calculated values.

った。高摩擦場の一つとして摩察因子が比較的単純な流 体を対象として高粘性流体中で系を加撚したときの撚の 云達とくに定常状熊においての撚数分布の平衡状態につ いて检討した。

高粘性流体としてクリセリンを用い，Fig.1の同心円 简回転装置により布呀を行ない，つぎの知見を得た。

1）流体中の回転系は，流体摩擦の影整により手長方 向に撚数の分布のあることが確認された。

2）一定張力下の流体中に扔ける定常回転中の糸の然 数分布を測定し、流体摩㜪抵抗モーメントの大きさは， クェット流として报った次式によって表わせた。

$$
M_{Y}=4 \pi h_{Y} \eta \Omega /\left(1 / R_{Y}{ }^{2}-1 / R_{P}{ }^{2}\right)
$$

3）Fig.3の装置によって，一定張力下に招ける系の 吅性率が測定できた。

4）系の㓮性率は，然数・張力に依存することが確認 された。

付記：本研究の一部は. 昭和 47 年 10 月第 6 回緎稚 7 学会連合研究発表会で講演した。

$$
\text { 文献 }
$$

1) 田中道一；山形大学紀要 (工学 ) 2, 223, (1953)
2) K. Baird ; J. Text. Inst., 50, T 475, (1959)

3）黑崎，近田，岡村；䄉学誌，24，573，(1968)

4) J. J. Thwaites ; J. Text. Inst., 61, T 116 (1970)

5）たとえば。図師督; 機誌..6，226(1953), J. W. S. Hearle; J. Text. Inst., 52, T 197 (1961)

6) M. M. Platt, W. G. Klein and W. J.Hambrger Text. Res. J., 28, 1, (1958)

7) W. E. Morton and F. Permanyer ; J. Text, Inst., 40, T 371, (1949)

P. Postle, P. Burton and M. Chaikin; J. Text. Inst., 55, T 448, (1964)

8）山崎, 岡林; 第 25 回緎䧽機械学会年次大会講演 論文集 (1972)

(補〕撚損失の理論值の算出は $G=A \cdot n \cdot T+B \cdot n+$ $C \cdot T+D$ とすれ代 (4).(5)，(6) 式上り

$\pi^{2} d^{4}(A \cdot n(x) \cdot T+B \cdot n(x)+C \cdot T+D) \cdot n(x) / 16$

$=4 \pi h_{W} \eta \Omega /\left(1 / R_{W}{ }^{3}-1 / R_{P}{ }^{2}\right)+4 \pi x \eta \Omega$

$/\left(1 / R_{Y}^{2}-1 / R_{P}^{2}\right)$

$\therefore n(x)=\frac{-f+\sqrt{f^{2}-4 \cdot e \cdot g}}{2 e}$

ただし， $e=\pi d^{4}(A \cdot T+B) / 16$

$f=\pi d^{4}(C \cdot T+D) / 16$

$g=4 \eta \Omega\left(h_{W} /\left(1 / R_{W}^{2}-1 / R_{P}^{2}\right)\right.$

$\left.+x /\left(1 / R_{Y}{ }^{2}-1 / R_{P}^{2}\right)\right\}$ 